\title{
„GODZINA MARSA” W ALZACJI. AFERA ZABERN 1913/1914
}

\author{
Piotr Szlanta
}

Uniwersytet Warszawski

\section{ABSTRACT}

\section{'AN HOUR OF MARS' IN ALSACE: THE ZABERN AFFAIR 1913/1914}

The article deals with the last serious internal crisis in Germany before the outbreak of the First World War. It was triggered in November, 1913, by the arrogant behaviour of a young lieutenant who offended local recruits in the Alsatian town of Zabern (Savern). Informed by the press, outraged inhabitants of Zabern protested on the streets, demanding appropriate punishment for the offender. His superiors decided to interfere in the competences of the civil authorities by introducing (illegally) a state of emergency in Zabern, rather than to back down under public pressure. The German parliament, not satisfied with the answer given by the chancellor to the MPs' questions on the affair, voted non-confidence for him. In the conflict between the civil and military authorities, Emperor William II completely took the side of the military, turning a deaf ear to the arguments of the civil servants. The affair of Zabern was widely regarded as tangible proof of the privileged status of the army within the German society and the Prussian militarism.

Key words: Prussia, militarism, Alsace-Lorraine, Zabern affair, 1913-1914.

Słowa kluczowe: Prusy, militaryzm, Alzacja-Lotaryngia, afera Zabern, 1913-1914.

Wojsko w Niemczech po 1871 roku cieszyło się ogromnym uznaniem społecznym. Wynikało to wielu przyczyn. Niemcy zjednoczyły się przecież nie w wyniku zabiegów liberalnych parlamentarzystów z okresu Wiosny Ludów (1848-1849), ale na skutek zwycięskich kampanii wojska pruskiego z lat 1864-1871. Same Prusy zresztą, które w opinii Napoleona wykluły się z kuli armatniej, osiągnęły w XVIII i XIX wieku mocarstwowy status dzięki sukcesom swego oręża.

Szacunek dla munduru przejawiał się w wilhelmińskich Niemczech na różne sposoby. Tysiące synów mieszczańskich po ukończeniu studiów wstępowało na rok do ochotniczej służby wojskowej, aby zdobyć upragniony stopień oficera rezerwy, 
rodzaj zastępczej nobilitacji. Bogdan Hutten-Czapski - ziemianin z Pomorza u schyłku swego barwnego i długiego życia, podczas którego piastował wysokie wojskowe i cywilne stanowiska, wspominał: „W zawodzie wojskowym znajdowałem w ciągu lat przeszło dwudziestu pełne zadowolenie. W gronie mych kolegów i na czele swych podwładnych czułem się zawsze szczególnie szczęśliwy [...]. Rzeczywiście, żaden z moich późniejszych awansów lub odznaczeń nie sprawił mi takiej radości jak zwykłe naszywki podoficerskie"'. W przededniu wybuchu Wielkiej Wojny Kyffhäuserbund, czyli związek weteranów i osób chcących upamiętniać zwycięskie wojny zjednoczeniowe, liczył 2,8 milionów członków. Czyniło to z niego największą organizację masową w Niemczech ${ }^{2}$.

Kult munduru przejawiał się czasem w kuriozalny sposób. W październiku 1906 roku w Köpenick pod Berlinem zwolniony niedawno $\mathrm{z}$ więzienia drobny przestępca Friedrich Voigt przebrał się w zakupiony od handlarza staroci mundur kapitana gwardii i przejął komendę nad przypadkowo napotkanymi na ulicy żołnierzami. Wraz z nimi udał się do ratusza, gdzie za rzekome malwersacje finansowe aresztował burmistrza i skarbnika. Nikt przy tym nie zażądał od niego dokumentów potwierdzających powierzone mu rzekomo zadanie - wystarczył sam widok munduru i zdecydowanie, niepozbawionego zapewne zdolności aktorskich, oszusta. Niczego niepodejrzewający żołnierze na rozkaz Voigta obsadzili i do wieczora okupowali budynek magistratu, nikogo z niego nie wypuszczając ani doń nie wpuszczając. Sam rzekomy oficer po cichu wymknął się z pieniędzmi skradzionymi z miejskiej kasy i zniknął ${ }^{3}$.

Pod koniec 1913 roku w Niemczech doszło do wybuchu poważnego kryzysu wewnętrznego, podczas którego naprzeciwko siebie stanęły: z jednej strony wspierane przez cesarza i prawicową część opinii publicznej wojsko, a z drugiej środowiska liberalne i lewicowe. Wywołało go karygodne postępowanie oficera jednego z pułków stacjonujących na zachodnich kresach państwa. W wyniku wojny francusko-niemieckiej Alzacja i znaczna część Lotaryngii zostały przyłączone do Rzeszy. Stworzono z nich Kraj Rzeszy (Reichsland), bezpośrednio podległy cesarzowi reprezentowanemu na miejscu przez mającego szerokie kompetencje namiestnika. Nie powołano tam natomiast parlamentu krajowego, a jedynie pochodzące $\mathrm{z}$ mianowania ciało doradcze przy namiestniku. Władzę ustawodawczą w Alzacji i Lotaryngii pełnił Reichstag. Obszar ten reprezentowało w nim 15 posłów, a pochodzących z niego rekrutów wcielano bezpośrednio do wojska pruskiego. Język francuski niemal całkowicie wyrugowano ze szkół. Gwoli sprawiedliwości należy jednak przyznać, że polityka językowa była na tych obszarach zdecydowanie bardziej liberalna niż w Poznańskiem ${ }^{4}$.

1 B. Hutten-Czapski, Sześćdziesiąt lat życia politycznego i towarzyskiego, t. I, Warszawa 1936, s. VIII, 28.

2 V. U11rich, Die Nervöse Großmacht 1871-1918. Aufstieg und Untergang des deutschen Kaiserreichs, Frankfurt am Main 2001, s. 397-404.

3 Der Fall Köpenick. Akten und zeitgenössische Dokumente zur Historie einer preußischen Moritat, Hrsg. W. Heidelmeyer, Frankfurt am Main 1968; W. Löschburg, Ohne Glanz und Gloria - Die Geschichte des Hauptmanns von Köpenick, Berlin 1998.

4 D. Schoenbaum, Zabern 1913. Consensus Politics in Imperial Germany, London 1982, s. $71-$ 94. Szerzej zob. E.R. Huber, Deutsche Verfassungsgeschichte seit 1789, Bd. 4: Struktur und Kriesen 
W 1911 roku zreformowano ustrój Alzacji-Lotaryngii, zwołując w niej w końcu parlament krajowy oraz przyznając jej prawo wysyłania delegatów do Bundesratu - organu reprezentującego na poziomie federalnym części składowe Rzeszy. Nie przekształcono jej jednak w pełen kraj związkowy na wzór Prus, Bawarii czy Saksonii. Ale i te skromne ustępstwa nie spodobały się niemieckim nacjonalistom spod znaku Związku Pangermańskiego, którzy zarzucali kanclerzowi Theobaldowi Bethmannowi-Hollwegowi wyprzedaż interesów narodowych. Alzatczycy i Lotaryńczycy mieli prawo czuć się w Rzeszy obywatelami drugiej kategorii. Przez władze niemieckie i pruskie byli traktowani z podejrzliwością. Tylko kilku z ponad 20 starostów prowincji było miejscowymi. Rozporządzenie z lata 1904 roku nakazywało, aby połowa urzędników pocztowych pochodziła z innych terenów Niemiec niż Alzacja-Lotaryngia ${ }^{5}$.

\section{PRZEBIEG WYPADKÓW W ZABERN}

Aferę, którą uznano za symbol pruskiego militaryzmu, sprowokowało zachowanie junkra z Prus Wschodnich, porucznika hrabiego Güntera von Forstnera. W momencie opisywanych wypadków nie osiągnął on nawet pełnoletności, gdyż miał nieco ponad 20 lat. Po ukończeniu szkoły kadetów w Gross Lichterfelde (obecnie dzielnica Berlina) odbył osiemnastomiesięczną praktykę w stopniu sierżanta. W 1912 roku otrzymał awans na stopień oficerski i przydział do 99. Pułku Piechoty, którego I i II batalion stacjonowały od 1890 roku w Zabern (franc. Saverne).

Było to leżące u podnóża Wogezów, oddalone w linii prostej o $30 \mathrm{~km}$ na północny zachód od Strasburga (1,5 godziny jazdy pociągiem) miasteczko, zamieszkane wówczas przez 8000-9000 osób. Biegła przez nie linia kolejowa Strasburg-Nancy-Paryż, którą przecinał kanał Ren-Marna. Zwane „perłą Wogezów” lub „miastem róż” było latem licznie odwiedzane przez - głównie francuskich - turystów ${ }^{6}$. Jego mieszkańcy wydawali się lojalni wobec Niemiec. Z okazji przyłączenia Alzacji i Lotaryngii do Rzeszy wysłali do Ottona von Bismarcka list dziękczynny. Aż do 1912 roku z okręgu wyborczego, na którego terenie leżało Zabern, do Reichstagu wybierano posła z partii wolnokonserwatywnej (Deutsche Reichspartei). Klub parlamentarny tego ugrupowania stale wspierał rząd. Dopiero w wyborach ze stycznia 1912 roku mandat z tego okręgu uzyskał lewicowy liberał. Garnizon wojsk pruskich stanowił największą instytucję społeczną miasta. Cywile i wojskowi żyli z sobą w nieustannym kontakcie. Wielu emerytowanych wojskowych (w tym co najmniej jeden z dowódców pułku płk Adolf Barth) po przejściu w stan spoczynku osiedliło się w Zabern. Na porządku

des Kaiserrreiches, Stuttgart 1969; S.Ch. Preibusch, Verfassungsentwicklungen im Reichsland ElsaßLothringen 1871-1918. Integration durch Verfassungsrecht?, Berlin 2006.

5 W.J. Mommsen, Bürgerstolz und Weltmachtstreben. Deutschland unter Wilhelm II. 1890 bis 1918, Berlin 1995, s. 395ff.

6 R.W. Mackey, The Zabern Affair, 1913-1914, Lanham 1991, s. 31. 
dziennym były małżeństwa mieszane między wojskowymi a mieszkankami miasta i okolic. Jeszcze przed wybuchem afery służba Forstnera nie przebiegała bez zarzutu. Kilka razy swym zachowaniem złamał regulamin?

W wydaniu z czwartku 6 listopada 1913 roku lokalna gazeta „Zabern Anzeiger” donosiła, że 28 października, podczas szkolenia nowo wcielonych rekrutów Forstner określał Alzatczyków obraźliwym mianem Wackes, bliskim znaczeniowo naszemu „cham” lub „prostak”. Stało się tak pomimo obowiązującego od 1903 roku rozkazu pułkowego zabraniającego używania tego słowa. Ponadto Forstner zachęcał żołnierzy do zdecydowanej odpowiedzi - łącznie z użyciem broni - na ewentualne zaczepki kierowane wobec nich podczas patrolowania miasta. Wyznaczył nawet nagrodę w kwocie 10 marek za zabicie prowokatora. Ze swej strony podoficer Wilhelm Höflich obiecał kolejne trzy marki ${ }^{8}$.

Już wieczorem w dniu publikacji pod mieszkaniem Forstnera zebrał się oburzony tłum, wznoszący antypruskie i profrancuskie okrzyki. W piątek 7 listopada gazeta powtórzyła te oskarżenia, wyrażając nadzieję, że w całej sprawie głos zabierze dowódca jednostki, pułkownik Ernst von Reuter. Nie bez znaczenia dla dalszego przebiegu kryzysu był charakter Reutera. Uchodził on za człowieka surowego i nieprzyjemnego w obyciu, choć mającego duże poczucie obowiązku. Pułkiem dowodził od listopada 1912 roku?.

Nie bacząc na nastroje społeczne, w sobotni wieczór 8 listopada kilku młodych oficerów, w tym Forstner, udało się do miejscowej gospody „Pod Karpiem”. Już w drodze do lokalu grupie wojskowych towarzyszył nieprzyjazny tłum. Atmosfera na miejscu była na tyle napięta i wroga wobec oficerów, że ci ostentacyjnie położyli na stoliku nabite pistolety. Do akcji wkroczył wówczas Reuter, który pospiesznie przybył do gospody (brak informacji o tym, kto go zawiadomił o narastającym kryzysie) i rozkazał swym podwładnym natychmiastowy powrót - w asyście patrolu wojska do koszar. Pułkownik usiłował słownie uspokoić klientów lokalu, argumentując, że wydarzenia z 28 października zostały zniekształcone przez prasę. Zresztą zaraz po pierwszej publikacji „Zaberner Anzeiger” Reuter zabronił żołnierzom rozmawiania $\mathrm{z}$ osobami postronnymi na tematy służbowe ${ }^{10}$.

Następnego dnia, w niedzielę 9 listopada, Forstner - zgodnie z grafikiem - pełnił służbę. Ze względu na wybory przedstawicieli do kasy chorych do Zabern zjechało tego dnia sporo mieszkańców okolicznych miejscowości. Gdy po południu porucznik przechodził z koszar jednego batalionu do koszar drugiego, został rozpoznany na ulicy. Zaczął za nim podążać wrogi mu tłum, wykrzykując pod jego adresem nieprzychylne komentarze i wygrażając mu pięściami. Według późniejszej relacji Forstnera

7 D. Schoenbaum, op. cit., s. 98-99; E. Schenk, Der Fall Zabern, Stuttgart 1927, s. 4-6.

8 M.P. Vollert, Für Ruhe und Ordnung. Einsätze des Militärs im Innern (1820-1918). PreuenWestfalen-Rheinprovinz, Bonn 2014, s. 128; H.-U. Wehler, Der Fall Zabern von 1913/14 als Verfassungskrise des Wilhelminischen Kaiserrechs [w:] idem, Krisenherde des Kaiserreichs 1871-1918. Studien zur deutschen Sozial- und Verfassungsgeschichte, Göttingen 1970, s. 72; R.W. Mackey, op. cit., s. $35-36$.

9 E. Schenk, op. cit., s. 4.

10 D. Schoenbaum, op. cit., s. 100-101; H-U. Wehler, op. cit., s. 79. 
w jego stronę polecieć miało około 20 kamieni wielkości kurzych jajek. W związku z tym otrzymał ochronę w postaci dwóch żandarmów i patrolu żołnierzy. Przybyli pospieszenie pułkownik i burmistrz Knoepffler nie potrafili uspokoić thumu. Policja i żandarmeria również były bezsilne. Reuter o godzinie 17.00 rozkazał żołnierzom i oficerom powrót z miasta do swych kwater. W końcu wezwano na pomoc straż pożarną. Strażacy jednak niechętnie polewali swych współobywateli. Ci zresztą, za względu na pochmurne niebo, mieli z sobą parasole, którymi bronili się przed strumieniami wody. Wkrótce ktoś przeciął węże strażackie. Ostatecznie to deszcz doprowadził do rozejścia się tłumów tego wieczoru. Mimo gęstniejącej atmosfery Reuter stał w progu swego domu, szyderczo śmiejąc się i na oczach 200-300 osobowego tłumu prowokacyjnie paląc cygaro. Policja i żandarmeria ukarały tego dnia około 20 osób mandatami w wysokości od 5 do 20 marek za zakłócanie porządku publicznego. Już wtedy Reuter ostrzegł starostę Georga Mahla, że jeśli sytuacja w mieście się nie uspokoi, będzie musiał ogłosić stan wojenny. Ten wyraził opinię, że taką decyzję może podjąć jedynie sam cesarz ${ }^{11}$.

Wydanie oświadczania w sprawie wydarzeń z 28 października zajęło Reuterowi prawie tydzień. Stwierdził w nim, że terminem Wackes Forstner nazwał nie wszystkich Alzatczyków, ale jedynie agresywnych awanturników celowo szukających zwady z żołnierzami na mieście. Porucznik miał także apelować do żołnierzy o nieodpowiadanie na prowokacje cywili i używanie siły tylko w samoobronie. Stanowisko to potwierdziło w swym oświadczeniu dowództwo XV Korpusu ze Strasburga, w skład którego wchodził 99. Pułk Piechoty. Po wydaniu komunikatów sprawa wydawała się dla wojska zamknięta. Uważano, że dotyczy ona kwestii wewnętrznych armii i opinia publiczna nie powinna się tym interesować, zwłaszcza że nikt z cywili nie złożył oficjalnej skargi. Ani dowództwo 99. Pułku Piechoty, ani dowództwo XV Korpusu nie uznało za stosowne poinformować opinii publicznej o karze sześciu dni aresztu domowego nałożonej na Forstnera. Pułkownik Ernst von Reuter i generał Berthold Deimling, dowódca XV Korpusu, nie docenili skali urazy społecznej i politycznego wymiaru sprawy. Zdaniem „Zaberner Anzeiger” wydarzenia miały jednak inny przebieg, niż przedstawiały to wspomniane oświadczenia armii, zarzucając tej ostatniej bagatelizowanie sprawy ${ }^{12}$.

Sam Reuter złożył natomiast podanie o dymisję z zajmowanego stanowiska i wyjechał na urlop. Zdążył się nawet pożegnać z korpusem oficerskim swej jednostki i zamówić wóz do przeprowadzki ${ }^{13}$. Wydawało się, że sprawa zostanie stopniowo wyciszona. Burmistrz spotkał się z lokalnymi przedsiębiorcami, prosząc ich o tonowanie nastrojów robotników. Apelował także do nauczycieli (wśród demonstrujących było sporo uczniów) o ostrzeżenie uczniów przed angażowaniem się w uliczne awantury, przestrzegając, że biedniejszym może zostać cofnięta dopłata do podręczników, a ewentualne notowanie przez policję może niekorzystnie wpłynąć na ich przyszłą służbę wojskową. Prosił także zastępcę dowódcy 99. Pułku Piechoty, podpułkownika

11 E. Schenk, op. cit., s. 12-13; Schulthess'Europäischer Geschichtskalender. Neue Folge. Zweiund neuniger Jahrgang 1913, Hrsg. L. Riek, München 1915 (dalej: Schulthess 1913), s. 351-352.

12 E. Schenk, op. cit., s. 8-10; D. Schoen baum, op. cit., s. 99; Schulthess 1913, s. 352-353.

13 D. Schoenbaum, op. cit., s. 103; E. Schenk, op. cit., s. 21. 
Sontaga, o to, aby młodzi oficerowie unikali pojawiania się w najbliższych dniach na ulicach miasta ${ }^{14}$.

Cesarz Wilhelm II nie przyjął jednak prośby Reutera o dymisję. W niedzielę 16 listopada nieoczekiwanie powrócił on z urlopu do Zabern, wezwany tam telegraficznie przez gabinet wojskowy cesarza zajmujący się kwestiami polityki personalnej $\mathrm{w}$ armii ${ }^{15}$. Choć nie znamy przyczyn tej decyzji, została ona przez mieszkańców miasta i lokalną prasę odebrana jako prowokacja. Po nieoczkiwanym powrocie Reutera, który zresztą nie miał dobrych relacji z Mahlem ${ }^{16}$, kryzys wszedł w nową fazę. Oliwy do ognia dolał dodatkowo kolejny artykuł „Zaberner Anzeiger” z soboty 15 listopada, w którym donoszono, że Forstner nakazał meldować się żołnierzom: „Jestem Wackes” (Ich bin ein Wackes). Ukazujący się w Strasburgu „Der Elsässer” poinformował, że na szkoleniu, które miało zniechęcić żołnierzy do ewentualnego wstępowania w szeregi Legii Cudzoziemskiej, porucznik obraźliwie wyrażał się o fladze francuskiej, mówiąc, że mogą oni na nią defekować. Oczywiście użył on innego, bardziej dosadnego sformułowania określającego tę czynność. Inny tekst informował czytelników o tym, że podobno podczas ostatnich letnich manewrów Forstner wypróżniał się w łóżku na kwaterze, którą wynajęło mu wojsko. Zaczęto go z tego powodu nazywać wulgarnym określeniem Bettschiesser ${ }^{17}$.

Po odbyciu kary, o której opinia publiczna nic nie wiedziała, Forstner - nie bacząc na wzburzone nastroje społeczne - zamiast nie wystawiać nosa poza mury koszar, dopóki sprawa nie przycichnie, ostentacyjnie pojawiał się na mieście w eskorcie czterech uzbrojonych żołnierzy. Jego przełożeni nie zdecydowali się, co wydawało się roztropnym wyjściem, na przeniesienie go do innej jednostki. Takie rozwiązanie sugerował zresztą namiestnik Alzacji i Lotaryngii Karl von Wedel. Aresztowano natomiast kilku żołnierzy podejrzanych o poinformowanie prasy o słowach Forstnera o francuskiej fladze. $Z$ tego powodu dokonano przeszukania $\mathrm{w}$ redakcji „Zaberner Anzeiger" celem znalezienia dowodów w sprawie przecieku. Władze cywilne w Strasburgu nie chciały się mieszać w kompetencje wojska, nakazując władzom lokalnym utrzymanie porządku publicznego i ochronę wojskowych przed poniżaniem ze strony cywili ${ }^{18}$.

\section{„GODZINA MARSA"}

Reuter stopniowo tracił cierpliwość, uznając, że władze cywilne nie są w stanie spacyfikować wrogich wojsku nastrojów. Gdy 26 listopada Forstner z kilkoma innymi oficerami wracał z gospody „Pod Karpiem”, towarzyszyła im około

\footnotetext{
E. Schenk, op. cit., s. 15; D. Schoenbaum, op. cit., s. 101-102.

Schulthess 1913, s. 361.

16 E. Schenk, op. cit., s. 17-18.

17 Ibidem, s. 18-20; D. Schoenbaum, op. cit., s. 103.

18 E. Schenk, op. cit., s. 22-26.
} 
pięćdziesięcioosobowa grupa wznosząca wrogie okrzyki. Dwie osoby z tej grupy zostały aresztowane i przekazane stróżom prawa. Po przesłuchaniu zatrzymanych oraz świadków zajścia policja zwolniła ich do domu, nie widząc podstaw do zatrzymania. Następnego dnia młodzież wspięła się na mury koszar, aby obserwować ćwiczenia gimnastyczne żołnierzy ${ }^{19}$.

Dla Reutera, zachęcanego do utrzymywania twardego stanowiska przez Deimlinga, miarka się przebrała. Postanowił przeprowadzić manifestację siły. 28 listopada przejął władzę w mieście i ogłosił stan oblężenia. W strategicznych punktach rozstawiono gotowe do strzału karabiny maszynowe. Wyprowadzona przez porucznika Schadta na ulice miasta kompania piechoty zajęła także urząd pocztowy, odcinając miejscowość od świata zewnętrznego. Przy akompaniamencie werbli patrole żołnierzy uzbrojonych w karabiny załadowane ostrą amunicją, z zatkniętymi na lufach bagnetami, aresztowały 27 osób. Jak się później okazało, byli to w przeważającej części zupełnie przypadkowi przechodnie, niemający nic wspólnego z wystąpieniami przeciwko armii. Ich jedyną „,winę” stanowił pośpiech lub śmiech na widok żołnierzy. Wśród aresztowanych znaleźli się między innymi strażak, który wybiegł z domu, uznając odgłos werbli za sygnał wzywający do walki z pożarem, student spieszący się na pociąg, człowiek z bólem zębów zmierzający szybkim krokiem do apteki, wracający z pracy robotnik, który - spiesząc się na obiad - chciał przejść przez kordon wojska, redaktor konserwatywnej gazety „Zaberner Wochenblatt”, a nawet wychodzący z pracy radca sądowy i prokurator. Tych dwóch ostatnich wkrótce zwolniono, resztę zaś spędzono do jednej z koszarowych, nieoświetlonych i nieogrzewanych piwnic, gdzie stłoczonych na zaledwie $20 \mathrm{~m}^{2}$ i zziębniętych (była późna jesień) przetrzymywano przez całą noc. Dopiero około godziny 22.00 uwięzionym dostarczono dwa koce, a rankiem następnego dnia podano kawę i chleb. Od około godziny 11.00 byli oni pojedynczo, pod eskortą czterech żołnierzy, prowadzeni do cywilnego sędziego, który po kolei zwalniał ich do domów. Wśród aresztowanych przeważali ludzie młodzi. Tylko $5 \mathrm{z}$ nich ukończyło 25. rok życia, a 16 miało 20 lat lub mniej. Najstarszy z nich miał 43, najmłodszy - zaledwie 15 lat.

W rozmowie z przedstawicielem miasta, który pod nieobecność Mahla (tego dnia służbowo przebywał w Strasburgu) i złożonego chorobą burmistrza przybył do dowództwa pułku z prośbą o zaprzestanie ingerencji wojska w kompetencje władz cywilnych, Reuter zadeklarował, że zdecydowany jest za pomocą wszelkich dostępnych środków przywrócić autorytet wojska. Wyraził przy tym żal, że w tej „godzinie Marsa" nie polała się krew ${ }^{20}$.

19 D. Schoenbaum, op. cit., s. 106; E. Schenk, op. cit., s. 27.

20 D. Schoenbaum, op. cit., s. 110-111; E. Schenk, op. cit., s. 28-33. 


\section{STANOWISKO CESARZA}

Informacje o wypadkach w Zabern szybko obiegły cały kraj. Jeszcze 28 listopada w trybie pilnym zebrała się rada gminy Zabern i w telegramach wysłanych do cesarza, namiestnika, kanclerza i ministra wojny poprosiła o podjęcie działań mających ochronić ludność miasta przed samowolą wojskowych. Radni wyrazili swe oburzenie wobec - ich zdaniem - bezprawnych i prowokacyjnych działań Reutera. Kilka dni później zebrani w Strasburgu burmistrzowie miasteczek Kraju Rzeszy przekazali burmistrzowi Zabern zapewnienie o swej solidarności. W ich ocenie wojsko, ingerując $\mathrm{w}$ policyjne kompetencje burmistrza, złamało prawo ${ }^{21}$. W samym Zabern burmistrz wzywał mieszkańców do wypełnienia poleceń policji i zachowania spokoju. Celem zbadania sprawy na miejscu ze Strasburga przyjechał tajny radca, a 1 grudnia po południu także dowódca 30. Brygady Artylerii, generał Kühne. Ściągnął on patrole wojska z ulic i nawiązał kontakt z władzami cywilnymi. Aby pokazać, iż spór został zakończony, pojawił się na ulicach w towarzystwie Mahla ${ }^{22}$.

Karl von Wedel stanowczo potępił - w jego ocenie - nieodpowiedzialne działania wojskowych w Zabern. Jeszcze przed wydarzeniami z 28 listopada poinformował cesarza, że ostatnie wypadki w tym mieście wywierają złe wrażenie na cywilach i źle nastrajają do państwa nawet przychylne mu dotąd kręgi miejscowego społeczeństwa. Skarżył się na Deimilinga, który w swych przemówieniach miał obrażać Alzatczyków, deklarując, że nie ugnie się pod presją ulicy i prasy ${ }^{23}$. Wedel usiłował przekonywać cesarza o tym, iż niepociągnięcie do odpowiedzialności Forstnera i Reutera przekreśli wysiłki mające zjednać Alzatczyków dla Rzeszy.

Wilhelm II nie podzielał jednak stanowiska swego namiestnika. Zdaniem monarchy sprawa miała wymiar konstytucyjny, gdyż dotyczyła jego uprawnień zwierzchnich nad armią (Kommandogewalt). Nie chciał nawet udzielić Wedlowi audiencji i całkowicie dał wiarę kręgom wojskowym, przekonującym go, że winę za zajścia ponosi wyłącznie żądna sensacji prasa i prowokatorzy, a Reuter postąpił słusznie, broniąc honoru armii i kładąc kres anarchii. Cesarz odmówił również przedyskutowania międzynarodowego wymiaru kryzysu (z wiadomych względów bacznie obserwowanego w sąsiedniej Francji) z odpowiednim urzędnikiem z MSZ, który przyjechał do Donaueschingen w Badenii, gdzie jak co roku o tej porze kajzer polował na lisy. Wbrew radom swego głównego adiutanta Hansa von Plessena nie zdecydował się na zmianę kalendarza swych zajęć i wcześniejszy powrót do stolicy. W telegramie z 29 listopada Wilhelm uznał, że władze cywilne w Alzacji-Lotaryngii zawiodły. W jego ocenie to nie namiestnik, ale dowódca korpusu ponosi główną odpowiedzialność za zachowanie porządku w prowincji ${ }^{24}$. Kilka dni później na marginesie jednego $\mathrm{z}$ artykułów prasowych poświęconych aferze monarcha zanotował, że stanowi ona najlepszy dowód na to, jak sprawnie (i to pod nosem władz cywilnych), przez nikogo

\footnotetext{
21 Schulthess 1913, s. 370, 372.

22 E. Schenk, op. cit., s. 34.

23 D. Schoenbaum, op. cit., s. 104-105.

24 J.C.G. Röh1, Wilhelm II. Der Weg in den Abgrund 1900-1941, München 2008, s. 1031-1033.
} 
nie niepokojeni i nie powstrzymywani Francuzi prowadzili swą wywrotową działalność. Prasa i parlamentarzyści jak zwykle mieli wyolbrzymiać kryzys ${ }^{25}$.

Wilhelm II wraz z Deimlingiem postanowili w trybie pilnym, mimo późnej jesieni, wysłać 99 . Pułk Piechoty na poligon. $Z$ jednej strony miało to zapobiec kolejnym incydentom, z drugiej zaś boleśnie uświadomić mieszkańcom Zabern, jakie ekonomiczne korzyści czerpią oni ze stacjonującego w ich mieście garnizonu. Zgodnie z rozkazem cesarza 7 grudnia żołnierze opuścili Zabern, udając się na odległy o około $30 \mathrm{~km}$ teren ćwiczeń wojskowych ${ }^{26}$.

Opisywana afera nie była zresztą pierwszą sprawą dotyczącą relacji cywili i wojskowych w Alzacji i Lotaryngii, w której Wilhelm II zabrał głos. W styczniu 1911 roku w Milusie (niem. Mülhausen) wybuchł konflikt pomiędzy lokalnym urzędnikiem a oficerem. Wtedy także, bez wnikania w meritum sporu, monarcha opowiedział się po stronie wojskowego. Jak uzasadniał, zasadniczą kwestię stanowiło zachowanie autorytetu armii. Obu antagonistów ostatecznie przeniesiono do innych miast, ale oficera na odchodne monarcha uhonorował wysokim odznaczeniem ${ }^{27}$. Podczas wizyty w Strasburgu w maju 1912 roku, zwracając się na uroczystym przyjęciu do burmistrza miasta, kajzer odgrażał się, że jeśli mieszkańcy Kraju Rzeszy nie zaprzestaną okazywania swego niezadowolenia, to on da im się poznać z innej strony, podrze konstytucję i wcieli to terytorium bezpośrednio do Prus. Owe słowa, wypowiedziane na zamkniętym spotkaniu z lokalnymi dygnitarzami, ktoś podsłuchał pod drzwiami i przekazał prasie ${ }^{28}$.

Wróćmy jednak do wydarzeń z przełomu lat 1913 i 1914. Znany ze swych szowinistycznych poglądów następca tronu, książę koronny Wilhelm, wysłał do garnizonu w Zabern telegram gratulacyjny, w którym zachęcał do utrzymania twardego kursu względem „,bezczelnego plebsu z Zabern” i „,panów tubylców”. „Walić mocno!” (Immer feste druff!') - wzywał następca tronu. W wyniku niedyskrecji któregoś z pracowników poczty aroganckie i pełne buty słowa przedostały się do prasy, dolewając oliwy do ognia ${ }^{29}$. Za przeciek zbiorowo ukarano dyscyplinarnie wszystkich pracowników urzędów pocztowych w Stuttgarcie i Zabern, przez które przechodził feralny telegram ${ }^{30}$. W podobnym tonie wypowiedział się na łamach ultrakonserwatywnej „Neue Preussische Zeitung” szef berlińskiej policji Traugott von Jagow, twierdząc, że pruskie wojsko w Alzacji i Lotaryngii działa jak ,prawie na wrogim terytorium”. Ponieważ wciąż toczyły się postępowania sądowe przeciw Reuterowi i Forstnerowi, wezwał on do powstrzymania się od komentarzy do momentu zapadnięcia wyroków ${ }^{31}$.

25 Ibidem, s. 1032.

26 Schulthess 1913, s. 401; D. Schoenebaum, op. cit., s. 128; H.-U. Wehler, op. cit., s. 86.

27 Ch. Clark, Wilhelm II. Die Herrschaft des letzten deutschen Kaisers, München 2008, s. 156-158.

28 A. König, Wie mächtig war der Kaiser? Kaiser Wilhelm II. zwischen Königsmechanismus und Polykratie von 1908 bis 1914, Stuttgart 2009, s. 47-49, 268.

29 A. Sommerfeld, Der Fall Zabern. Die Kronprinzen-Depesche und die öffentliche Meinung, Berlin 1914; M.P. Vollert, op. cit., s. 131.

${ }^{30}$ H.-U. Wehler, op. cit., s. 76.

31 Schulthess 1913, s. 440-444; E. Schenk, op. cit., s. 62-66; D. Schoenenbaum, op. cit., s. 140-141. 
Aroganckie i bezprawne działania władz wojskowych oraz brak odpowiedniej reakcji rządu wywołały poruszenie w całym kraju. Dyskutowano nad legalnością wprowadzenia stanu wyjątkowego przez Reutera. Część prawników uważała, że niepublikowany nigdzie dekret królewski sprzed niemal 100 lat - w związku z tym, że Prusy po 1848 roku przekształciły się w państwo konstytucyjne - w ogóle nie obowiązuje. Sprawą zainteresował się Reichstag. Posłowie wszystkich partii, z wyjątkiem konserwatystów i antysemitów, zwłaszcza zaś socjaldemokraci i lewicowi liberałowie, wyrażali swe oburzenie, domagając się debaty parlamentarnej z udziałem kanclerza. Zgłosili oni kilka interpelacji do kanclerza i ministra wojny, pytając szefa rządu między innymi o to, co zamierza uczynić, aby chronić ludność Alzacji i Lotaryngii przed obrażaniem jej przez wojskowych ${ }^{32}$.

Dosłownie w przeddzień debaty w Reichstagu, 2 grudnia, Forstner ponownie przypomniał o sobie szerszej opinii publicznej. Podczas ćwiczeń wojskowych w miejscowości Dettweiller wśród gapiów przyglądających się żołnierzom dostrzegł śmiejącego się, niepełnosprawnego ucznia szewskiego. Jego zachowanie uznał za obrazę armii i przy próbie aresztowania ranił „,sprawcę” cięciem szabli przez głowę ${ }^{33}$. Była to jedyna osoba ranna podczas całej afery. Ten incydent dolał tylko oliwy do ognia i podwyższył temperaturę debaty publicznej o pozycji wojska w państwie.

Posiedzenie Reichstagu w sprawie zajść w Zabern rozpoczęło się 3 grudnia. W odpowiedzi na interpelacje poselskie Bethmann-Hollweg przyjął koncyliacyjny ton. Przyznał, że Forstner popełnił wykrocznie, lecz dopuścił się go za murami koszar i miało ono bardzo małe znaczenie, niewspółmierne do nadanego mu później rozgłosu. Wziął za to w obronę postępowanie Reutera, uznając je za motywowane dążeniem do opanowania wymykającej się spod kontroli sytuacji oraz koniecznością obrony honoru i czci armii. Przypomniał posłom incydenty, w których znieważano oficerów na ulicach Zabern. „Królewski mundur musi być poszanowany w każdych okolicznościach" ${ }^{34}$ - z naciskiem podkreślił kanclerz. Wyprowadzenie 28 listopada wojska na ulice Zabern i dokonane wówczas aresztowania miały zapobiec jeszcze gorszym wypadkom ${ }^{35}$. Potem - już zupełnie w innym tonie - przemówił Erich von Falkenhayn. W jego ocenie w całej sprawie nie chodziło o mniejsze czy większe uchybienia służbowe ze strony młodego porucznika, ale o celową strategię, która przez kampanię prasową, organizowanie manifestacji i systematyczne znieważanie wojska ma doprowadzić do uzyskania bezprawnego wpływu na proces decyzyjny władz. Ustąpienie przed nieuzasadnionymi żądaniami dałoby - zdaniem ministra - tylko chwilowy spokój, gdyż środowiska, którym zależy na upadku armii, ponowiłyby swe ataki, licząc na doprowadzenie do chaosu. „Armia jest bowiem, jak wiadomo, częścią narodu i mogę powiedzieć: nie najmniej ważną"36 - argumentował Falkenhayn, przypominając posłom, że bez jej wysiłku nie powstałby

32 R.W. Mackey, op. cit., s. 163-173.

33 J.W. Gerard, op. cit., s. 66; M.P., Vollert, op. cit., s. 129; D. Schoenbaum, op. cit., s. 112-113.

34 Schulthess 1913, s. 387; Verhandlungen des Reichstags. Stenographische Berichte. XIII Legislaturperiode. I. Session, Band 291, Berlin 1914, s. 6157.

35 Schulthess 1913, s. 384-388.

36 Ibidem, s. 389; Verhandlungen des Reichstags..., s. 6159. 
budynek, w którym się znajdowali. Była to czytelna aluzja do roli wojska w procesie zjednoczenia Niemiec. Bezpieczeństwo Rzeszy zależy od dzielności i niezawodności armii, a ta jak tlenu potrzebuje władzy, dyscypliny i poczucia honoru. $\mathrm{W}$ trakcie swego przemówienia Falkenhayn niemal wdał się w pyskówkę z posłami opozycji. Przewodniczący Reichstagu musiał kilkakrotnie uciszać wzburzoną salę ${ }^{37}$.

W debacie, jaka nastąpiła po powyższych wystąpieniach przedstawicieli władz, głos zabrali posłowie. Według przedstawiciela katolickiej Partii Centrum Konstantina Fehrenbacha wyjęcie armii spod działania prawa i wydanie władz cywilnych na samowole ze strony władz wojskowych oznaczać będzie finis Germaniae. Wysyłanie kilkuosobowych patroli mających asystować oficerom w kupnie papierosów czy kakao nazwał czystą donkiszoterią. Inny poseł tego ugrupowania Eugen Ricklin stwierdził, że niegdyś armia zdobyła Alzację i Lotaryngię, lecz teraz ją utraciła. Według narodowego liberała, posła Fritza von Calkera, wojsko uprawiało politykę prestiżu, ale najbardziej jego autorytetowi zagrażało bezprawie. Pytał retorycznie, czy przyszłością Alzacji i Lotaryngii ma być dyktatura wojskowa. Zdaniem socjaldemokraty Georga Weilla kanclerz skapitulował przed wojskiem. Obecnie wcale nie chodziło już o małe miasteczko, ale o gwarancję praw obywatelskich w całym państwie. Na zakończenie dwudniowej debaty 4 grudnia parlamentarzyści przyjęli uchwałę uznającą odpowiedź kanclerza za niewystarczającą. W konsekwencji Reichstag większością 293 głosów (przy 54 przeciwnych i czterech wstrzymujących się) przegłosował votum nieufności wobec szefa rządu ${ }^{38}$. Nie miało to jednak żadnych praktycznych konsekwencji, gdyż zgodnie z konstytucją powoływanie i odwoływanie kanclerza leżało w wyłącznej gestii cesarza. Ustąpienia Bethmanna-Hollwega i Falkehayna domagali się także uczestnicy manifestacji, jakie w kilkunastu miastach zwoływała w tych dniach SPD. Sam kanclerz paradoksalnie wzmocnił swą pozycję, gdyż Wilhelm II był wyraźnie zadowolony ze sposobu, w jaki bronił on przed posłami uprawnień korony.

Sprawa Zabern powracała jeszcze w kolejnych dniach grudnia 1913 roku na posiedzeniach Reichstagu. Konserwatywny poseł Westarp bronił stanowiska Reutera. Jak argumentował, autorytet armii będzie zagrożony, jeśli w przypadku konieczności obrony oficer nie będzie mógł wyciągnąc szpady i będzie zmuszony liczyć jedynie na pióro prawnika. Uznał, że była to próba demokratyzacji armii i podporządkowania jej prasie i thumowi ${ }^{39}$.

\section{EPILOG}

Emocje wokół afery w Zabern po świętach Bożego Narodzenia i Nowym Roku wyraźnie opadły. Obradujący w dniach 5-10 stycznia 1914 r sąd wojskowy

37 Schulthess 1913, s. 388-390.

38 Verhandlungen des Reichstags..., s. 6198-6200; Schulthess 1913, s. 377-401; D. Schoen baum, op. cit., s. 121-125.

39 D. Schonebaum, op. cit., s. 131-132. 
w Strasburgu rozpatrywał sprawę Reutera i Schadta, oskarżonych o bezprawne przejęcie kompetencji władz cywilnych 28 listopada, bezprawne aresztowanie 27 osób, użycie siły podczas aresztowań i naruszenie miru domowego (część aresztowanych wyciągano $\mathrm{z}$ domów, gdy próbowali się w nich schronić). W procesie zeznawało aż 143 świadków. Na mocy wyroku z 10 stycznia obu oskarżonych uniewinniono. Sąd uznał bowiem, że działali w stanie wyższej konieczności ${ }^{40}$. Oficerowie przysłuchujący się posiedzeniu sądu na miejscach dla publiczności przyjęli wyrok z nieskrywaną radością, spiesząc Reuterowi i Schadtowi z gratulacjami. Za nieuzasadnione użycie siły w Detweiller sąd wojskowy pierwszej instancji skazał Forstnera na 43 dni aresztu. Porucznik odwołał się jednak od wyroku. Sąd wyższej instancji uwolnił go od tego zarzutu, uznając, że oficer działał w poczuciu zagrożenia ${ }^{41}$.

Podobnej wyrozumiałości nie miał sąd wobec trzech alzackich żołnierzy oskarżonych o poinformowanie prasy o słowach Forstnera na temat francuskiej flagi. W dniu 11 grudnia $\mathrm{z}$ ust sędziego wojskowego w Strasburgu usłyszeli oni wyroki od trzech do sześciu tygodni aresztu wojskowego za poinformowanie osób z zewnątrz o przebiegu wypadków za murami koszar ${ }^{42}$.

Afera w Zabern w styczniu 1914 roku była jeszcze przedmiotem zainteresowania parlamentarzystów. Sprawę poruszył w pruskiej Izbie Panów hrabia York von Wartenburg, twierdząc, że ataki na pruską armię godzą w miejsce samych Prus w Rzeszy. Jego zdaniem demokracja usiłowała rozszerzyć swe wpływy kosztem cesarza i rządu, podważając kompetencje dowódcze monarchy ${ }^{43}$. Zajmowały się nią także obie izby landtagu Alzacji i Lotaryngii. Podczas debat gwałtownie atakowano postępowanie wojska, uniewinniające wyroki sądów, brak przeprosin i istnienie w Niemczech partii wojskowej. Druga izba jednogłośnie przyjęła rezolucję, w której uznała, że brakowało podstaw prawnych i powodów do ingerencji wojska w sferę kompetencji władz cywilnych. Podziękowano także Reichstagowi za wzięcie ludności Alzacji i Lotaryngii w ochronę, wzywano do reformy sądownictwa wojskowego, precyzyjnego rozgraniczania kompetencji różnych władz oraz poszerzenia niezależności prowincji w ramach Rzeszy Niemieckiej ${ }^{44}$. Nieco łagodniejszą rezolucję i już nie jednomyślnie przyjęła również wyższa izba landtagu Alzacji i Lotaryngii ${ }^{45}$.

Srodowiska konserwatywne broniły status quo. Zdaniem jego reprezentantów siły liberalne i lewicowe postanowiły wykorzystać drobny incydent $\mathrm{z}$ odległego garnizonu w celu podstępnego wymuszenia demokratyzacji ustroju państwa i podważenia jego podstaw ustrojowych, w tym miejsca Prus w Rzeszy i kompetencji samego monarchy. Poza artykułami prasowymi czy wypowiedziami parlamentarzystów powyższa wykładnia wydarzeń z Zabern wyrażała się także na inne sposoby. Po uniewinnieniu Reuter otrzymal - bagatela - 65000 listów i kartek pocztowych

40 R.W. Mackey, op. cit., s. 119-132; E. Schenk, op. cit., s. 53-62.

41 D. Schoenbaum, op. cit., s. 135-136; Schulthess' Europäischer Geschichtskalender. Neue

Folge. Dreißigster Jahrgang 1914, Hrsg. W. Stahl, München 1917 (dalej: Schulthess 1914), s. 15.

42 Schulthess 1913, s. 361, 432-433.

43 Schulthess 1914, s. 9.

44 Schulthess 1914, s. 23-26.

45 Ibidem, s. 41-42. 
z gratulacjami. Przebywający na zimowym wygnaniu na poligonie pułk dostawał liczne paczki ze skarpetkami, papierosami i kiełbasą. Jeden darczyńca wysłał żołnierzom 3000 marek w gotówce ${ }^{46}$.

Niezależnie od zakończonych spraw przeciw Reuterowi, Forstnerowi i Schadtowi w marcu 1914 roku w sądach znajdowało się ponad 20 pozwów cywilnych, w tym wniesionych przez osoby aresztowane w „godzinie Marsa”, które uznały, że noc w piwnicy zrujnowała im zdrowie. Aby ostatecznie zamknąć całą sprawę, wojsko gotowe było na zawarcie ugód pozasądowych. Koszty odszkodowań Wedel szacował na nie więcej niż 2500 marek $^{47}$.

Pod koniec stycznia 1914 roku Wilhelm II wyraził zgodę na przeniesienie Reutera i Forstnera do innych jednostek. Na odchodne Reuter otrzymał od swego monarchy pruski Order Czerwonego Orła III Klasy. Forstnera przeniesiono natomiast do jednostki w Bydgoszczy. W samym Zabern na krótko pojawił się w południe 2 lutego. Policjant przekonał go jednak, aby nie nocował w mieście i po załatwieniu ostatnich spraw złapał popołudniowy pociąg do Strasburga. Tak też się stało. Pobyt porucznika w mieście przebiegł bez jakichkolwiek incydentów. 99. Pułk Piechoty Zabern powrócił z poligonu dopiero w kwietniu 1914 roku. Ze względu na olbrzymie koszty całej operacji, których z pewnością nie chciałby zatwierdzić Reichstag, cesarz nie zdecydował się na jego relokację do innego garnizonu ${ }^{48}$. W maju 1914 roku kajzer zwolnił Wedla (zresztą na jego własną, złożoną jeszcze w styczniu, prośbę) z funkcji namiestnika Alzacji i Lotaryngii, zastępując go mającym ultrakonserwatywne poglądy Hansem von Dallwitzem ${ }^{49}$.

\section{PODSUMOWANIE}

Omawiana afera urosła do rangi symbolu niemieckiego militaryzmu, rozumianego jako dominacja wojskowych w życiu publicznym, nietykalność armii i bezsilność parlamentu w starciu ze strukturami armii. Rozpoczęła się ona od drobnego, lokalnego incydentu, gdy przełożeni nie chcieli lub nie byli w stanie ukarać i utemperować krnąbrnego porucznika. Armia miała możliwości załagodzenia sporu już w jego pierwszej fazie. Można było na przykład od razu poinformować opinię publiczną (nawet kanałami nieoficjalnymi) o nałożonej na Forstnera karze aresztu czy też przenieść go w trybie pilnym do III batalionu 99. Pułku Piechoty, stacjonującego poza Zabern. Reuterowi i Deimlingowi zabrakło jednak wrażliwości na odczucia cywilów. Brak wystarczającej reakcji wojska na ekscesy porucznika (w ocenie lokalnej społeczności) doprowadził do eskalacji konfliktu. W wyniku bezprawnej demonstracji siły z 28 listopada sprawa nabrała zaś ogólnonarodowego wymiaru

\footnotetext{
46 D. Schoenbaum, op. cit., s. 141, 147.

47 Ibidem, s. 163.

48 Ibidem, s. 164-167.

49 Schulthess 1914, s. 58, 198.
} 
(o międzynarodowych reperkusjach), przeradzając się w konstytucyjny spór o rolę armii w państwie i charakter relacji między władzą cywilną i wojskową. Środowiska domagające się demokratyzacji ustroju w Niemczech przegrały tę batalię.

Afera, będąca kolejnym dowodem braku wyczucia politycznego ze strony monarchy, pokazała dobitnie, że mimo upływu 42 lat od momentu przyłączenia Alzacji i Lotaryngii do Rzeszy niemieckie władze wojskowe wciąż traktowały jej mieszkańców jak obywateli drugiej kategorii, niemal jak ludność okupowaną. Dla kręgów wojskowych Kraj Rzeszy stanowił przede wszystkim wysuniętą, nadgraniczną rubież o dużym znaczeniu dla obronności państwa. Wszelkie ustępstwa wobec mieszkańców prowincji miały być niedopuszczalnym przejawem słabości i godzić w obronność Rzeszy. Klucz do skutecznego zarządzania tym strategicznym terytorium wojskowi widzieli w gotowości do użycia siły, a nie w partnerskim, opartym na wzajemnym zaufaniu dialogu ze społeczeństwem. Na to nałożyły się także kwestie ambicjonalne, zarówno między decydentami władz różnych szczebli, jak i młodzieżą w mundurach (Forstnerem) i bez nich (uczniami miejscowych szkół, młodymi robotnikami, szyprami barek $)^{50}$.

\section{BIBLIOGRAFIA}

\section{Źródła}

Gerard J.W., My Four Years in Germany, New York 1917.

Hutten-Czapski B., Sześśdziesiąt lat życia politycznego i towarzyskiego, Warszawa 1936.

Schulthess' Europäischer Geschichtskalender. Neue Folge. Dreißigster Jahrgang 1914, Hrsg. W. Stahl, München 1917.

Schulthess' Europäischer Geschichtskalender. Neue Folge. Zweiund neuniger Jahrgang 1913, Hrsg. L. Riek, München 1915.

Sommerfeld A., Der Fall Zabern. Die Kronprinzen-Depesche und die öffentliche Meinung, Berlin 1914.

Verhandlungen des Reichstags. Stenographische Berichte. XIII Legislaturperiode. I. Session, Band 291, Berlin 1914.

\section{Opracowania}

Clark Ch., Wilhelm II. Die Herrschaft des letzten deutschen Kaisers, München 2008.

Craig G., The Politics of Prussian Army 1640-1945, London 1964.

Der Fall Köpenick. Akten und zeitgenössische Dokumente zur Historie einer preußischen

Moritat, Hrsg. W. Heidelmeyer, Frankfurt am Main 1968.

50 H.U. Wehler, op. cit., s. 87-88; Verhandlungen des Reichstags ..., s. 6156. 
Huber E.R., Deutsche Verfassungsgeschichte seit 1789, Bd. 4: Struktur und Kriesen des Kaiserrreiches, Stuttgart 1969.

König A., Wie mächtig war der Kaiser? Kaiser Wilhelm II. zwischen Königsmechanismus und Polykratie von 1908 bis 1914, Stuttgart 2009.

Löschburg W., Ohne Glanz und Gloria - Die Geschichte des Hauptmanns von Köpenick, Berlin 1998.

Mackey R.W., The Zabern Affair, 1913-1914, Lanham 1991.

Mommsen W.J., Bürgerstolz und Weltmachtstreben. Deutschland unter Wilhelm II. 1890 bis 1918, Berlin 1995.

Mommsen W.J., War der Kaiser an allem schuld? Wilhelm II. und die preussich-deutschen Machteliten, Berlin 2005.

Preibusch S.Ch., Verfassungsentwicklungen im Reichsland Elsaß-Lothringen 1871-1918. Integration durch Verfassungsrecht?, Berlin 2006.

Röh1 J.C.G., Wilhelm II. Der Weg in den Abgrund 1900-1941, München 2008.

Salmonowicz S., Prusy. Dzieje państwa i spoteczeństwa, Warszawa 1998.

Schenk E., Der Fall Zabern, Stuttgart 1927.

Schoenbaum D., Zabern 1913. Consensus Politics in Imperial Germany, London 1982.

Szlanta P., Lekarz naszych dusz. Wyobrażenia o wojnie przed 1914 r. [w:] Wojna w Europie Środkowo-Wschodniej z perspektywy interdyscyplinarnej, red. J. Getka, J. Grzybowski, R. Kramar, Warszawa 2015, s. 39-50.

Szlanta P., Wilhelm II. Ostatni z Hohenzollernów, Warszawa 2015.

Ullrich V., Die Nervöse Großmacht 1871-1918. Aufstieg und Untergang des deutschen Kaiserreichs, Frankfurt am Main 2001.

Vollert M.P., Für Ruhe und Ordnung. Einsätze des Militärs im Innern (1820-1918). Preuen-Westfalen-Rheinprovinz, Bonn 2014.

Wehler H.-U., Der Fall Zabern von 1913/14 als Verfassungskrise des Wilhelminischen Kaiserrechs [w:] H.-U. Wehler, Krisenherde des Kaiserreichs 1871-1918. Studien zur deutschen Sozial- und Verfassungsgeschichte, Göttingen 1970. 


\section{ANEKS}

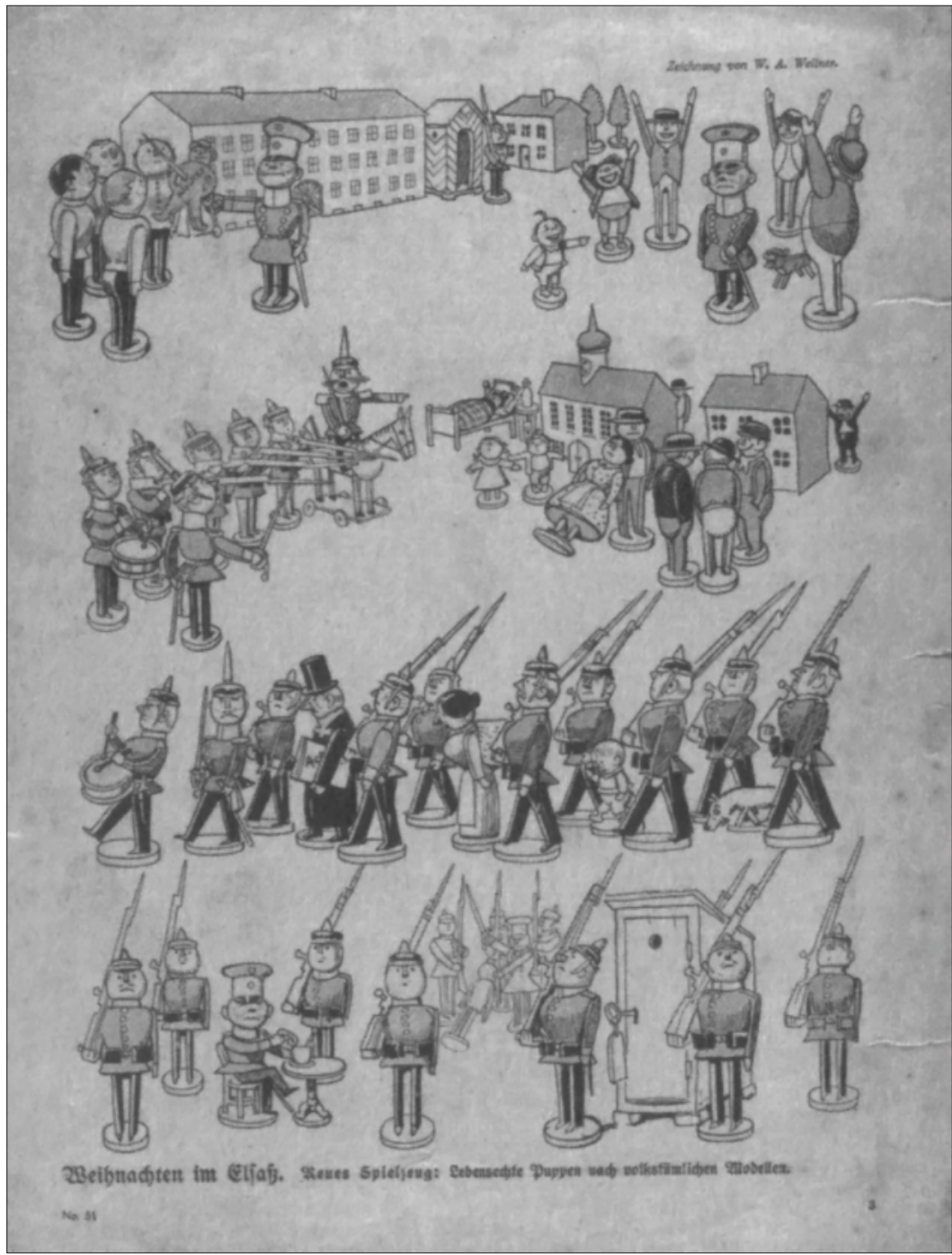

Rysunek 1. „Boże Narodzenie w Alzacji. Nowa zabawka: lalki jak żywe według ludowego wzoru”. Karykatura z epoki

Źródło: „Lustige Blätter” 1913, nr 51. 


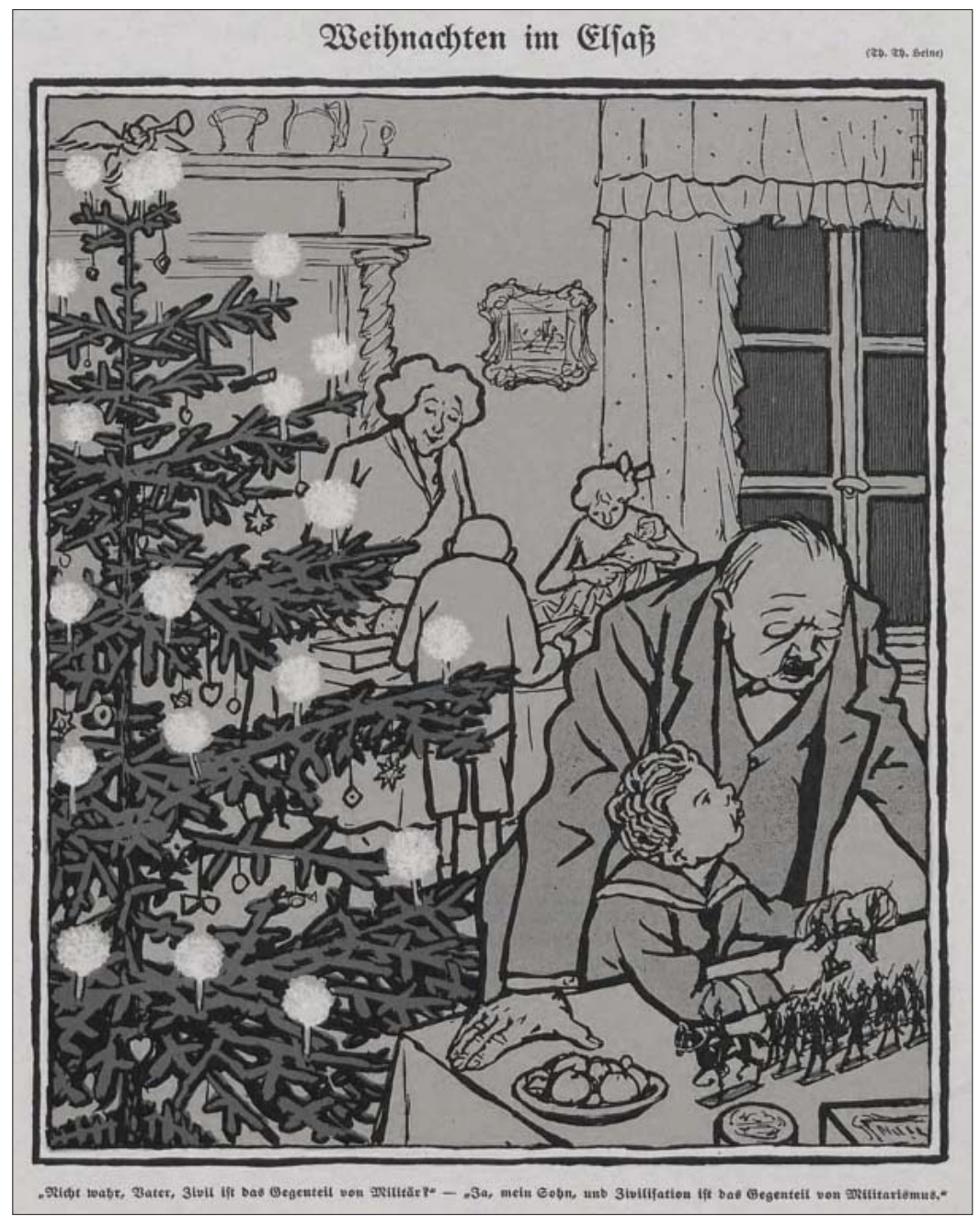

Rysunek 2. „Boże Narodzenie w Alzacji: »Tato, czy cywil to przeciwieństwo żołnierza?«, »Tak, mój synu, a cywilizacja jest przeciwieństwem militaryzmu «". Karykatura z epoki

Źródło: „Simplicissimus”, 22 grudnia 1913. 


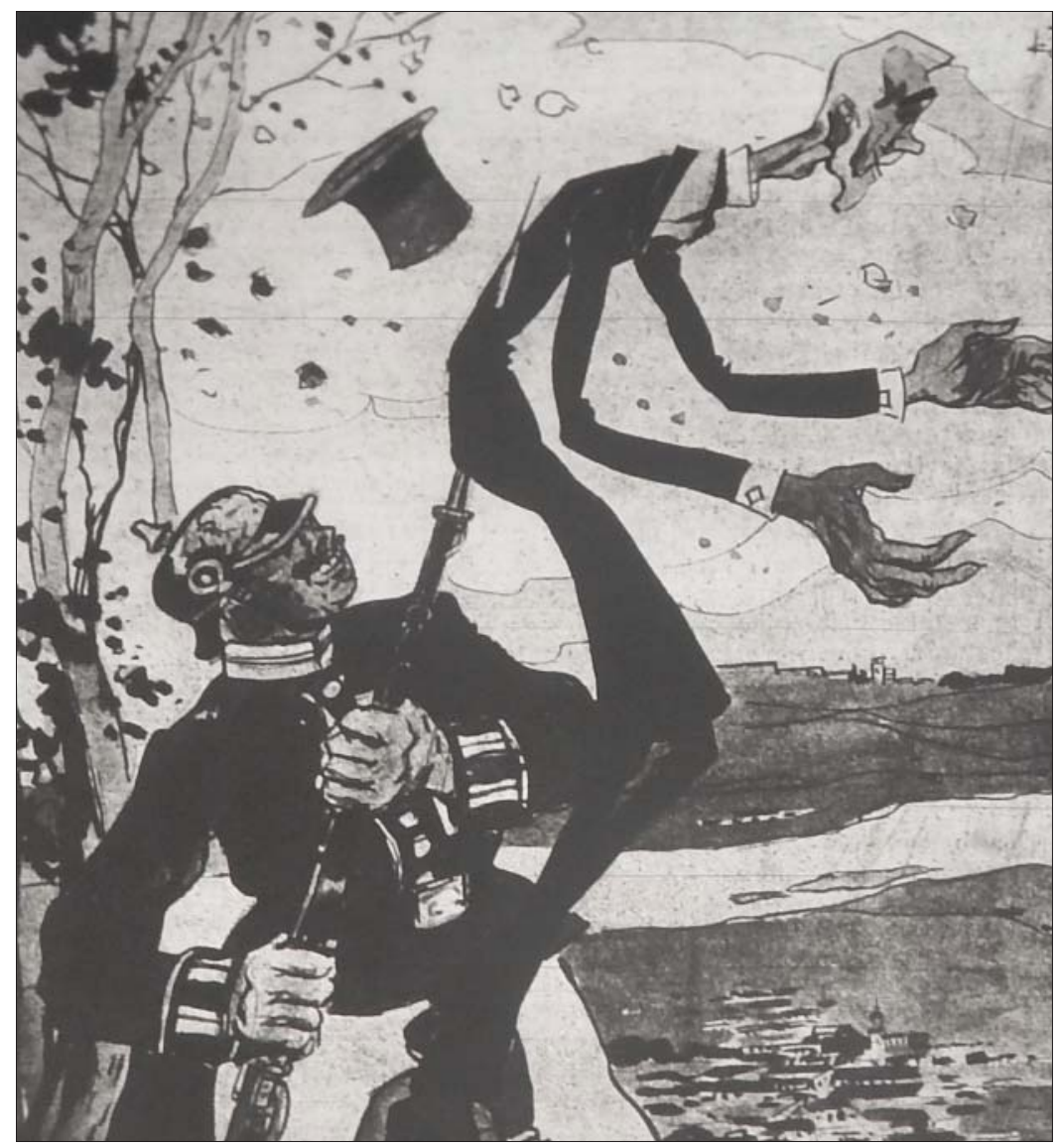

Rysunek 3. „Główny ustęp z mowy v. Bethmanna w parlamencie niemieckim: »Niech się dowie cały świat, co stwierdzam z własnej nieprzymuszonej woli, że postępowanie pułkownika v. Reutera i porucznika Forstnera z ludnością miasteczka Saverne było nie tylko bez zarzutu, ale i wysoce taktowne«". Karykatura z epoki

Źródło: „Mucha” (Warszawa), 12 grudnia 1913. 